Hydrology and Earth System Sciences, 7(1),87-96 (2003) C EGU

\title{
A standardised method for measuring in situ denitrification in shallow aquifers: numerical validation and measurements in riparian wetlands
}

\author{
J.M. Sánchez-Pérez ${ }^{1}$, C. Bouey ${ }^{1}$, S. Sauvage ${ }^{1}$, S. Teissier ${ }^{1}$, I. Antiguedad ${ }^{2}$ and P. Vervier ${ }^{1}$ \\ ${ }^{1}$ Laboratoire d'Ecologie des Hydrosystèmes (LEH, FRE CNRS-UPS 2630), 29 rue Jeanne Marvig, F-31055 Toulouse Cédex, France \\ ${ }^{2}$ Group of Hydrogeology. University of Basque Country - Euskal Herriko Unibertsitatea, 48940 Leioa, Basque Country, Spain
}

Email for corresponding author : sanchez@ecolog.cnrs.fr

\begin{abstract}
A tracer test to examine in situ denitrification in shallow groundwater by a piezometer with a packer system used bromide as a tracer of dilution and acetylene (10\%) to block the denitrification process at the nitrous oxide stage. During the test, dissolved oxygen, nitrate $\left(\mathrm{NO}_{3}^{-}\right)$, bromide (Br-), nitrous oxide $\left(\mathrm{N}_{2} \mathrm{O}\right)$ and dissolved organic carbon (DOC) were measured. To calibrate the experimental method, comparison with numerical simulations of the groundwater transfer were carried out, taking into account the environmental characteristics. The method was tested by measurements undertaken in different environmental conditions (geology, land use and hydrology) in two riparian wetlands.

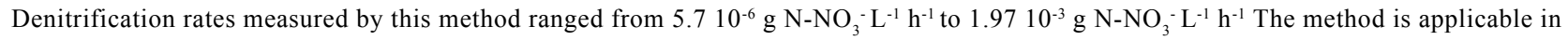
shallow aquifers with a permeability from $10^{-2}$ to $10^{-4} \mathrm{~m} \mathrm{~s}^{-1}$.

Keywords : denitrification, shallow aquifer, groundwater modelling, wetlands, nitrate-nitrogen, packer system
\end{abstract}

\section{Introduction}

Riparian zones can play an important role in reducing nitrate input from groundwater to river water and, thus, in regulating the flux of nitrate of agricultural origin. The capacity of these interface zones to retain and remove diffuse contamination of agricultural origin in the transversal axis (river - aquifer) has been the subject of numerous studies (Peterjohn and Correll, 1984; Pinay and Décamps, 1988; Gregory et al., 1991; Correll et al., 1992; Sánchez-Pérez et al., 1991a, b; Sánchez-Pérez and Trémolières, 2003, 1997; Cooper, 1990; Jordan et al., 1993; Cey et al., 1999).

One of the major processes associated with the removal of nitrate was denitrification (Jacobs and Gilliam, 1985; Cooper, 1990; Lowrance et al., 1995; Burt et al., 1999). The denitrification rate has been quantified widely in different types of media or aquifer lithology and climate (Cooper, 1990; Pinay et al., 1995).

While denitrification has been studied and quantified within soils, few studies have measured this process within an alluvial aquifer. The role of riparian vegetation in decreasing the nitrate concentrations from aquifers has been demonstrated predominantly by a decreasing nitrate concentration gradient from groundwater to rivers (Hill and
Shackleton, 1989; Haycock and Pinay, 1993). The role of the denitrification process within this decreasing nitrate gradient has been measured by running in situ denitrification rate analyses in the surface layer of the riparian soils (Pinay et al., 1993). However, if the objective is to address the reduction of nitrate coming from groundwater by riparian zones, one must consider that the greatest flux of nitrate (ie., that passing through the saturated zone of the aquifer) is often disconnected from the surface soil layer. Therefore, it is essential to be able to measure denitrification within the saturated zone in order to compare and quantify the role of microbial denitrification and root uptake processes quantitatively.

Denitrification refers to the dissimilatory reduction of one or both of the ionic nitrogen oxides (nitrates $\mathrm{NO}_{3}^{-}$, nitrites $\mathrm{NO}_{2}^{-}$) to the gaseous oxides (nitric oxide $\mathrm{NO}$, nitrous oxide $\mathrm{N}_{2} \mathrm{O}$ ), which may themselves be further reduced to dinitrogen $\mathrm{N}_{2}$ by nitrous oxide reductase. Denitrification occurs in anaerobic media, when nitrate and organic matter can be found by bacteria (Payne, 1973; Knowles, 1982).

The four reductases involved in denitrification are susceptible to inhibition by a variety of compounds. The $\mathrm{N}_{2} \mathrm{O}$ reductase, located in the bacterial membrane is inhibited 
by acetylene $\left(\mathrm{C}_{2} \mathrm{H}_{2}\right)$ which is a non-competitive inhibition (inhibition independent of substrate concentration). The presence of acetylene in the medium causes the stoichiometric accumulation of $\mathrm{N}_{2} \mathrm{O}$ as the terminal product of the reduction of other oxides, instead of an accumulation of dinitrogen (Knowles, 1982); the latter is difficult to measure as the reaction is blocked by the acetylene at the $\mathrm{N}_{2} \mathrm{O}$ phase. The levels of $\mathrm{N}_{2} \mathrm{O}$ can then be measured accurately.

The acetylene blocking method has been heavily criticised (Knowles, 1990), mainly because of a lack of $\mathrm{N}_{2} \mathrm{O}$ reductases inhibition (Seitzinger et al., 1993). However, this method provides a valid basis for measurements of denitrification (Balderston et al., 1976 ; Yoshinari and Knowles, 1976 ; Yeomans and Beauchamp, 1978; Knowles, 1981). Therefore, it is deemed appropriate for in situ denitrification measurements in groundwater.

Denitrification was measured within the saturated zone of a porous aquifer by acetylene blocking method. The saturated zone was sampled by a piezometer, which became both the injecting point for acetylene and the sampling site for measuring the rate of denitrification. The objective was to standardise a method to measure denitrification in situ within shallow alluvial riparian groundwaters.

\section{Principles of the method}

Since the same piezometer is used to inject acetylene and to collect water sampled for denitrification analysis, it is necessary to check how the injected products are dispersed and diluted around the piezometer. A numerical model supports these experiments to compute groundwater motion and, consequently, to check if what has been injected is really sampled. This method was tested in the Garonne floodplain (France) and in the Vitoria-Gasteiz aquifer (Spain). In the Garonne floodplain, six piezometers were sampled; two were in a riparian wetland, two in a poplar tree plantation and two in agricultural land. In the Vitoria-Gasteiz Aquifer, two piezometers were sampled at two depths, in a marny substrate and in a silty soil.

\section{Material and methods}

\section{WATER SAMPLING}

Nineteen litres of groundwater were sampled with a peristaltic pump in a piezometer using a packer system (UVITEC, Austria) after removal of ten times the volume of water from the piezometer. This system enables water to be pumped from the aquifer rather than just from the piezometer at the same depth during the experiment.

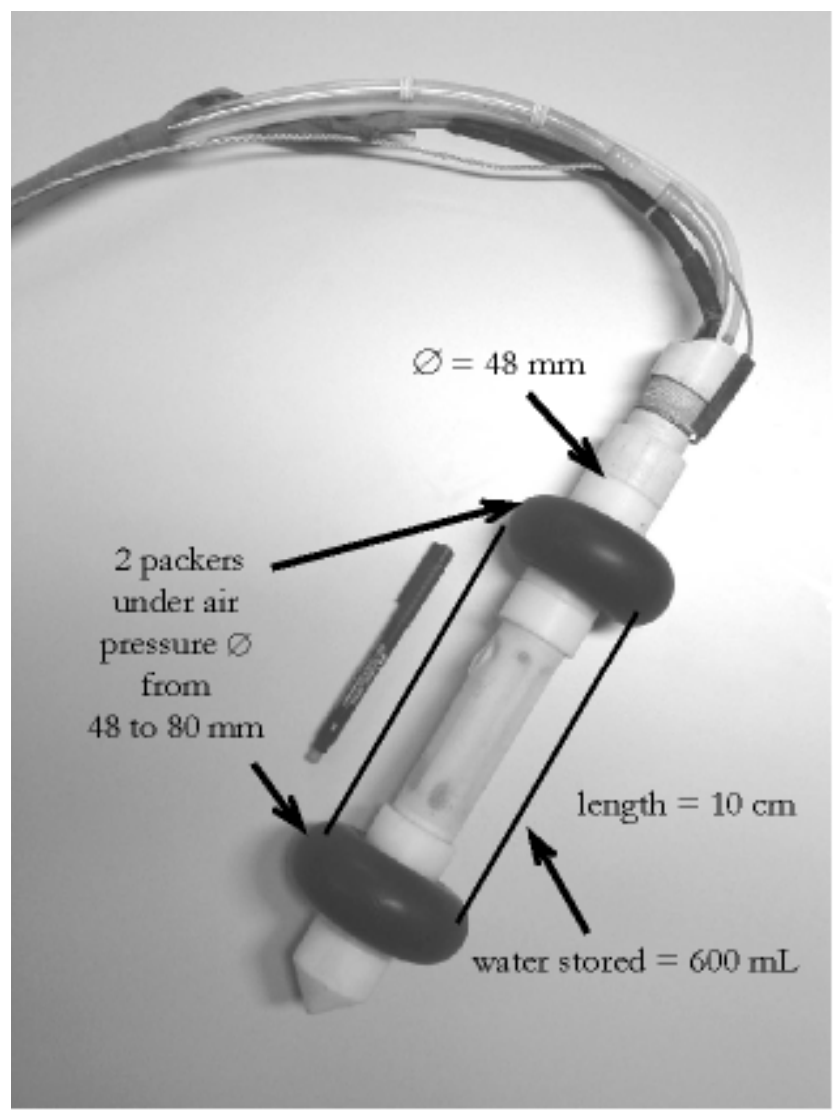

Fig. 1. The packer system.

The packer system (Fig. 1), consists of a pump within a $48 \mathrm{~mm}$ in diameter tube, $10 \mathrm{~cm}$ long, which can store 600 $\mathrm{ml}$ of water; above and below this tube are two packers that can be inflated from 48 to $80 \mathrm{~mm}$. Water is pumped at a pre-determined depth, and stored in a 25 litre container. One litre of a solution containing bromide (as $\mathrm{NaBr}$, final concentration $13.4 \mathrm{mg} \mathrm{l}^{-1}$ of $\left.\mathrm{Br}^{-}\right)$and acetylene $(10 \%)$ is added to the pumped water sample. Bromide is used as a dilution tracer and acetylene is used to block the denitrification process at the $\mathrm{N}_{2} \mathrm{O}$ step. Bromide and acetylene were added to the sampled water in a sampling bag (container). The $\mathrm{C}_{2} \mathrm{H}_{2}$ was obtained by an exothermic reaction between water $(20 \mathrm{ml})$ and calcium carbide, using speleological equipment; then it is injected by bubbling into the water until the $\mathrm{C}_{2} \mathrm{H}_{2}$ has displaced the air. The $\mathrm{C}_{2} \mathrm{H}_{2}$ injection in the sampling bag is considered complete when the $\mathrm{C}_{2} \mathrm{H}_{2}$ goes out of the water sample bottle through a thin tube. It is considered that $\mathrm{N}_{2} \mathrm{O}$ is diluted in the aquifer in the same way as bromide. The injections are done with all the precautions necessary to prevent oxygen from entering the container.

After mixing, the 20 litre solution is re-injected with the peristaltic pump into the piezometer, at the same depth at 

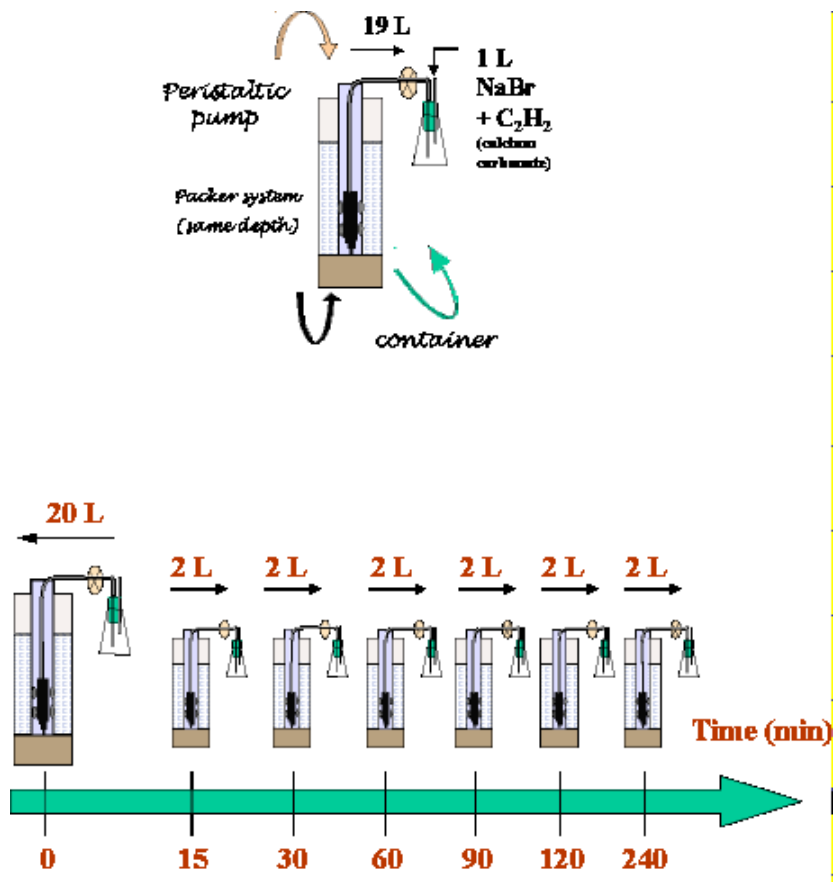

Fig. 2. Application of the methodology in the field.

which the water had previously been sampled. $\mathrm{t}_{0}$ is the time at which the solution has been injected entirely. Two litres of water, assumed to be mixed with acetylene and bromide, were sampled successively in the same piezometer 0,15 , 30, 60, 90, 120 and 240 minutes after injection (Fig. 2).

\section{WATER ANALYSIS}

Water samples were collected in glass bottles and filtered through glass fibre filters (Whatman GFF). Nitrate $\left(\mathrm{NO}_{3}^{-}-\right.$ $\mathrm{N}$ ) and bromide (Br) were analysed by ionic chomatography using a DIONEX system. Water samples collected for dissolved organic carbon (DOC) were filtered using precombusted GFF filters $\left(450^{\circ} \mathrm{C}\right.$ for $\left.4 \mathrm{~h}\right)$ and analysed using a platinum catalyst at $650^{\circ} \mathrm{C}$ (Shimadzu, Model TOC 5000). A multi-parameter probe (YSI 6920) provided physicochemical data at each time (temperature, dissolved oxygen, conductivity, $\mathrm{pH}$, redox potential).

A small sample $(3 \mathrm{ml})$ was also injected with a plastic syringe in a vacuum tube (Venoject, Terumo; evacuated blood collection tubes, diameter $=13 \mathrm{~mm}$, length $=75 \mathrm{~mm}$, vacuum volume $5 \mathrm{ml}$ ), with formaldehyde $(0.5 \%)$ to prevent bacteria from continuing denitrification. $\mathrm{N}_{2} \mathrm{O}$ was further analysed by a gas chromatograph equipped with a ${ }^{63} \mathrm{Ni}$ electron capture detector. The carrier gas was a mixture of argon $(95 \%)$ and methane $(5 \%)$ under 1 bar. The inert gases were separated on a Poparak Q column at $80^{\circ} \mathrm{C}$, the injector temperature was $130^{\circ} \mathrm{C}$ and the detector temperature $280^{\circ} \mathrm{C}$.
The calculation takes into account the $\mathrm{N}_{2} \mathrm{O}$ mass in the sampled water (using $\mathrm{N}_{2} \mathrm{O}$ solubility, Weiss and Price, 1980) plus the $\mathrm{N}_{2} \mathrm{O}$ mass in the gaseous phase minus the $\mathrm{N}_{2} \mathrm{O}$ mass introduced during equilibration.

\section{CALCULATIONS OF THE DENITRIFICATION RATE}

The $\mathrm{N}_{2} \mathrm{O}$ concentrations measured in the experiment were corrected for dilution by dispersion and advection processes, using a dilution factor determined from the bromide concentrations. This dilution factor is defined as the ratio of the injected bromide in the piezometer $\left[\mathrm{Br}^{-}\right]_{\mathrm{t} 0}$ to the bromide concentration at time of sampling ti $\left(\left[\mathrm{Br}^{-}\right]_{\mathrm{t} 0} /\right.$ $\left.\left[\mathrm{Br}^{-}\right]_{\mathrm{i}}\right)$. Corrected $\mathrm{N}_{2} \mathrm{O}$ concentrations were calculated as the product of the measured $\mathrm{N}_{2} \mathrm{O}$ concentration at time $\mathrm{t}$ and the dilution factor at the same time.

After the injection, the $\mathrm{N}_{2} \mathrm{O}$ production time rose regularly to a plateau. The maximum slope of the tangent to this curve in the ascending part represents the $\mathrm{N}_{2} \mathrm{O}$ production rate $\left(=\Delta \mathrm{N}_{2} \mathrm{O}\right.$ corrected $\left./ \Delta \mathrm{t}\right)$. The calculated $\mathrm{N}_{2} \mathrm{O}$ production rate is finally transformed to give the $\mathrm{N}_{-} \mathrm{NO}_{3}^{-}$denitrification rate.

\section{GROUNDWATER MODELLING}

To validate the method and determine the limits of the validation, the experiment was modelled. Transient flow and conservative solute transport during the experiment were simulated. Each transient step unit corresponds to each step of the experiment (injecting period, pumping periods, latent periods between pumps).

The model used, Processing Modflow (PM5), offers a totally integrated simulation system for modelling groundwater flow and transport processes (Chiang et al., 1998). The program MODFLOW-96 (McDonald and Harbaugh, 1998) simulated three-dimensional groundwater flow during the whole experiment and revealed the impact of the injection and the different pumping operations in the piezometer. MT3D is a modular 3D solute transport model for MODFLOW for simulation of advection, dispersion and chemical reaction. The physical characteristics of the aquifer used in the model correspond to those of the study site as presented in Table 1.

\section{STUDY SITES}

This method was tested in the Garonne alluvial floodplain (south-western France) and in the quaternary aquifer of Vitoria-Gasteiz (North Spain). The French site is located on the Monbequi study site ( $40 \mathrm{~km}$ north of Toulouse). The Spanish site is located on the Arkaute site near the city of Vitoria (northern Spain). At the Monbequi site, the denitrification studies were made in six piezometers $(30$ 
Table 1. Characteristics of the piezometers tested with the method.

\begin{tabular}{|c|c|c|c|c|c|c|c|c|}
\hline Location & $\begin{array}{l}\text { Piezometer } \\
\text { number }\end{array}$ & $\begin{array}{c}\text { Soil } \\
\text { use }\end{array}$ & $\begin{array}{l}\text { Diameter of } \\
\text { drilling } \\
(\mathrm{mm})\end{array}$ & $\begin{array}{l}\text { Diameter of } \\
\text { piezometer } \\
(\mathrm{mm})\end{array}$ & $\begin{array}{l}\text { Total } \\
\text { depth } \\
(m)\end{array}$ & $\begin{array}{l}\text { Nature of } \\
\text { deposit }\end{array}$ & $\begin{array}{l}\text { Depth of } \\
\text { denitrification } \\
\text { measurement }\end{array}$ & $\begin{array}{l}\text { Nature of the } \\
\text { deposit at the } \\
\text { depth of the } \\
\text { denitrification } \\
\text { measurement }\end{array}$ \\
\hline Monbequi & P8 & $\begin{array}{l}\text { Poplar } \\
\text { plantation }\end{array}$ & $76 \mathrm{~mm}$ & $\begin{array}{l}\text { Int. : } 52 \mathrm{~mm} \\
\text { Ext. : } 60 \mathrm{~mm}\end{array}$ & $4.9 \mathrm{~m}$ & Sand & $3.1 \mathrm{~m}$ & Sand \\
\hline Monbequi & P9 & $\begin{array}{l}\text { Riparian } \\
\text { zone }\end{array}$ & $76 \mathrm{~mm}$ & $\begin{array}{l}\text { Int. : } 52 \mathrm{~mm} \\
\text { Ext. : } 60 \mathrm{~mm}\end{array}$ & $6 \mathrm{~m}$ & $\begin{array}{l}\text { Gravel and } \\
\text { sand }\end{array}$ & $4.1 \mathrm{~m}$ & Gravel and sand \\
\hline Monbequi & P10 & $\begin{array}{l}\text { Poplar } \\
\text { plantation }\end{array}$ & $76 \mathrm{~mm}$ & $\begin{array}{l}\text { Int. : } 52 \mathrm{~mm} \\
\text { Ext. : } 60 \mathrm{~mm}\end{array}$ & $6 \mathrm{~m}$ & $\begin{array}{l}\text { Gravel and } \\
\text { sand }\end{array}$ & $4.2 \mathrm{~m}$ & $\begin{array}{l}\text { Gravel and } \\
\text { sand }\end{array}$ \\
\hline Monbequi & P13 & $\begin{array}{l}\text { Riparian } \\
\text { zone }\end{array}$ & $76 \mathrm{~mm}$ & $\begin{array}{l}\text { Int. : } 52 \mathrm{~mm} \\
\text { Ext. : } 60 \mathrm{~mm}\end{array}$ & $3 \mathrm{~m}$ & Sand and clay & $1.7 \mathrm{~m}$ & $\begin{array}{l}\text { Sand and } \\
\text { clay }\end{array}$ \\
\hline Monbequi & P26 & $\begin{array}{l}\text { Agricultural } \\
\text { land }\end{array}$ & $76 \mathrm{~mm}$ & $\begin{array}{l}\text { Int. : } 52 \mathrm{~mm} \\
\text { Ext. : } 60 \mathrm{~mm}\end{array}$ & $5.5 \mathrm{~m}$ & $\begin{array}{l}\text { Gravel and } \\
\text { sand }\end{array}$ & $4 \mathrm{~m}$ & Gravel and sand \\
\hline Monbequi & P29 & $\begin{array}{l}\text { Agricultural } \\
\text { land }\end{array}$ & $76 \mathrm{~mm}$ & $\begin{array}{l}\text { Int. : } 52 \mathrm{~mm} \\
\text { Ext. : } 60 \mathrm{~mm}\end{array}$ & $7.5 \mathrm{~m}$ & $\begin{array}{l}\text { Gravel and } \\
\text { sand }\end{array}$ & $6 \mathrm{~m}$ & $\begin{array}{l}\text { Gravel and } \\
\text { sand }\end{array}$ \\
\hline Arkaute & P5 & Meadows & $125 \mathrm{~mm}$ & $\begin{array}{l}\text { Int. : } 80 \mathrm{~mm} \\
\text { Ext. : } 90 \mathrm{~mm}\end{array}$ & $12 \mathrm{~m}$ & $\begin{array}{l}\text { Clay and sand. } \\
\text { Marl at } 4 \mathrm{~m}\end{array}$ & $3.5 \mathrm{~m} 8 \mathrm{~m}$ & $\begin{array}{l}\text { Clay } \\
\text { Marls }\end{array}$ \\
\hline Arkaute & P11 & Meadows & $125 \mathrm{~mm}$ & $\begin{array}{l}\text { Int. : } 80 \mathrm{~mm} \\
\text { Ext. : } 90 \mathrm{~mm}\end{array}$ & $8 \mathrm{~m}$ & $\begin{array}{l}\text { Sand, clay } \\
\text { and gravel. } \\
\text { Marl at } 4 \mathrm{~m}\end{array}$ & $6 \mathrm{~m}$ & Marls \\
\hline
\end{tabular}

tests): two in a riparian zone (P9 and P13), two in a poplar plantation (P8 and P10) and two in agricultural land (P26 and P29). At the Arkaute site, measurements were made in two different piezometers (three tests) : P11 and P5 (at two different depths). The characteristics of the piezometers are given in Table 1.

\section{Results}

\section{BACKGROUND CONDITIONS}

Nitrate concentrations ranged from 2.76 to $16.45 \mathrm{mg} \mathrm{N}^{-1}$ except for one sample at a depth of $8 \mathrm{~m}$ in piezometer 11 in the Vitoria Gasteiz Aquifer; this had a nitrate-nitrogen content concentration of $40.90 \mathrm{mg} \mathrm{N}^{-1}$. Concentrations in each piezometer were rather stable over time (Table 2).

Dissolved oxygen ranged from 1.4 to $9.3 \mathrm{mg} \mathrm{l}^{-1}$. Dissolved organic carbon (DOC) ranged from 0.96 to $1.99 \mathrm{mg} \mathrm{l}^{-1}$, except for the $3.5 \mathrm{~m}$ sample in piezometer 5 in the Vitoria-
Gasteiz aquifer, which had a DOC concentration of 3.56

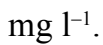

\section{INJECTION TEST RESULTS}

Figure 3 shows how bromide and $\mathrm{N}_{2} \mathrm{O}$ behave with time in piezometer $\mathrm{P} 8$ at Monbequi. The kinetic of the denitrification is exponential. The calculations of the denitrification rate are represented in Table 3 . The concentrations in nitrate and in DOC remained constant during the measurement. Pumping groundwater causes oxygenation but, during the injection of water into the piezometer, the dissolved oxygen concentration decreased to its initial value.

Figure 4 shows two other cases for which the method is not applicable. In the first case (P26 at Monbequi), dilution is too high and inhibition of denitrification is not guaranteed. It gives very high dilution rates and the $\mathrm{N}_{2} \mathrm{O}$ correction for dilution consequently provides a very high and inaccurate $\mathrm{N}_{2} \mathrm{O}$ production rate. There may have been a problem with 
Table 2. Background concentration of $\mathrm{N}^{-\mathrm{NO}_{3}}{ }_{3}, \mathrm{DOC}$ and Dissolved oxygen in the piezometers (mean $\pm \mathrm{SE}$ ). $\mathrm{N}=$ number of samples. $\mathrm{SE}=$ standard error.

\begin{tabular}{lccccc}
\hline Localisation & $N$ & $\begin{array}{c}\text { Piezometer } \\
\text { number }\end{array}$ & $\begin{array}{c}\mathrm{N}^{-\mathrm{NO}_{3}^{-}} \\
\left(\mathrm{mg} l^{-1}\right)\end{array}$ & $\begin{array}{c}\text { Disolved Oxygen } \\
\text { range }\left(\mathrm{mg} l^{-1}\right)\end{array}$ & $\begin{array}{c}\text { DOC } \\
\left(\mathrm{mg} l^{-1}\right)\end{array}$ \\
\hline Monbequi & 6 & P8 & $13.43 \pm 2.47$ & $4.5-7.1$ & $1.54 \pm 0.11$ \\
Monbequi & 5 & P9 & $8.19 \pm 0.44$ & $1.6-5.4$ & $1.60 \pm 0.17$ \\
Monbequi & 5 & P10 & $13.08 \pm 1.27$ & $1.4-6.2$ & $1.17 \pm 0.13$ \\
Monbequi & 5 & P13 & $7.05 \pm 1.47$ & $1.0-3.5$ & $1.75 \pm 0.16$ \\
Monbequi & 5 & P26 & $11.42 \pm 1.07$ & $5.4-7.7$ & $1.58 \pm 0.18$ \\
Monbequi & 5 & P29 & $13.44 \pm 0.09$ & $5.4-8.1$ & $1.10 \pm 0.05$ \\
Arkaute & 2 & P5 & $1.21 \pm 0.09$ & $0.6-1.4$ & 3.56 \\
Arkaute & 1 & P11 & $40.90 \pm 0.75$ & 5.1 & - \\
\hline
\end{tabular}

the watertightness of the packer system and bromide may have leaked. This situation can be compared with the case of a very permeable medium.

In the second case (piezometer P5 at Arkaute), in a clayey soil, the injected water was blocked in the piezometer. The decrease in $\mathrm{Br}^{-}$concentration between injection and sampling at time $t_{15}$ is due to the dilution by the water stored in the piezometer. These results show that the $\mathrm{N}_{2} \mathrm{O}$ production rate is very low.

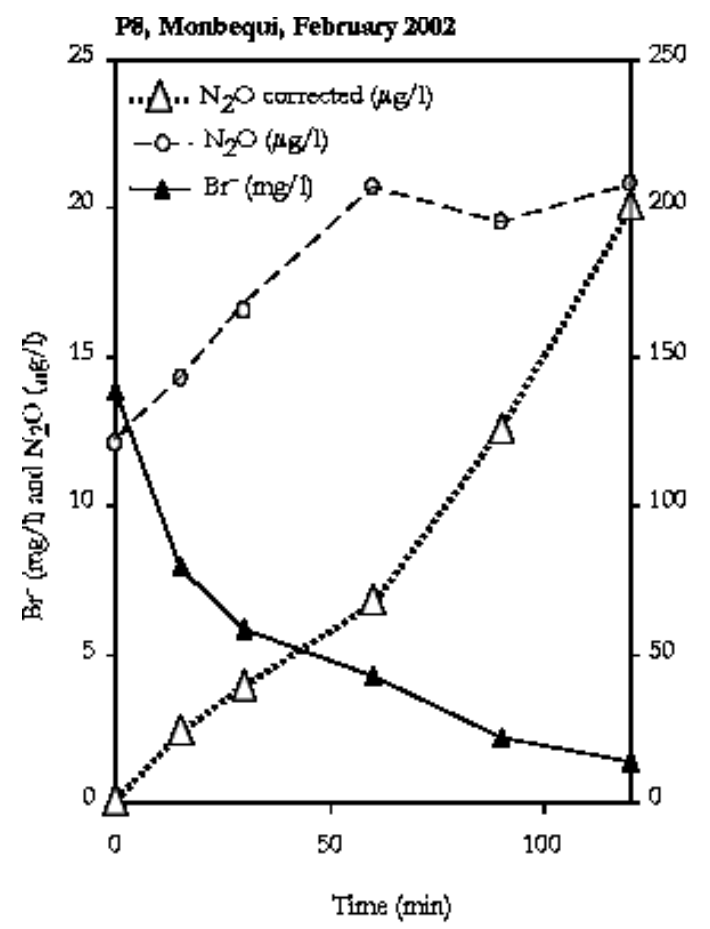

The average rate of nitrate consumption measured with this method ranged from $6.5110^{-6} \mathrm{~g} \mathrm{~N}^{-N^{-}} \mathrm{L}_{3}^{-1} \mathrm{~h}^{-1}$ to 2.06

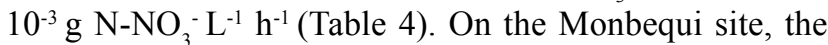
rate of $\mathrm{N}_{2} \mathrm{O}$ production differs among the three compartments. The riparian zone showed a maximum

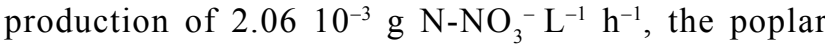
plantation of $0.9710^{-3} \mathrm{~g} \mathrm{~N}^{-N^{-}} \mathrm{L}^{-1} \mathrm{~h}^{-1} \mathrm{~h}$ while in the agricultural land the minimum denitrification measured was

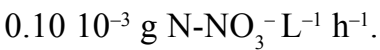

Fig. 3. Bromide, $\mathrm{N}_{2} \mathrm{O}$ and corrected $\mathrm{N}_{2} \mathrm{O}$, DOC, Dissolved oxygen and nitrogen nitrate concentrations versus time in a piezometer during an injection test. 
Table 3. Example of calculation of the denitrification rate (Piezometer P8, Monbequi, February 2002).

\begin{tabular}{|c|c|c|c|c|c|c|}
\hline Time (min) & $\begin{array}{l}\mathrm{N}_{2} \mathrm{O} \\
\text { produced } \\
\left(m g l^{-1}\right)\end{array}$ & $\begin{array}{l}B r- \\
\left(m g l^{-1}\right)\end{array}$ & $\begin{array}{l}\text { Dilution rate } \\
{\left[B r_{t 0} / B r_{t i}\right]}\end{array}$ & $\begin{array}{l}\mathrm{N}_{2} \mathrm{O} \\
\text { corrected } \\
\left(\mu g l^{-1}\right)\end{array}$ & $\begin{array}{l}\mathrm{N}_{2} \mathrm{O} \\
\text { produced } \\
\left(\mu \mathrm{g} \mathrm{l}^{-1} \mathrm{~min}^{-1}\right)\end{array}$ & $\begin{array}{l}\mathrm{N}-\mathrm{NO}_{3}^{-} \\
\text {denitrified } \\
\left(\mathrm{g} l^{-1} h^{-1}\right)\end{array}$ \\
\hline 0 & 12.1 & 13.9 & 1.0 & 12.1 & & \\
\hline 15 & 14.3 & 7.9 & 1.1 & 25.1 & & \\
\hline 30 & 16.6 & 5.9 & 1.8 & 39.3 & & \\
\hline 60 & 20.7 & 4.2 & 4.3 & 68.0 & 0.94 & $3.7710^{-5}$ \\
\hline 90 & 19.5 & 2.1 & 6.2 & 126.3 & & \\
\hline 120 & 20.8 & 1.4 & 9.3 & 201.5 & & \\
\hline
\end{tabular}
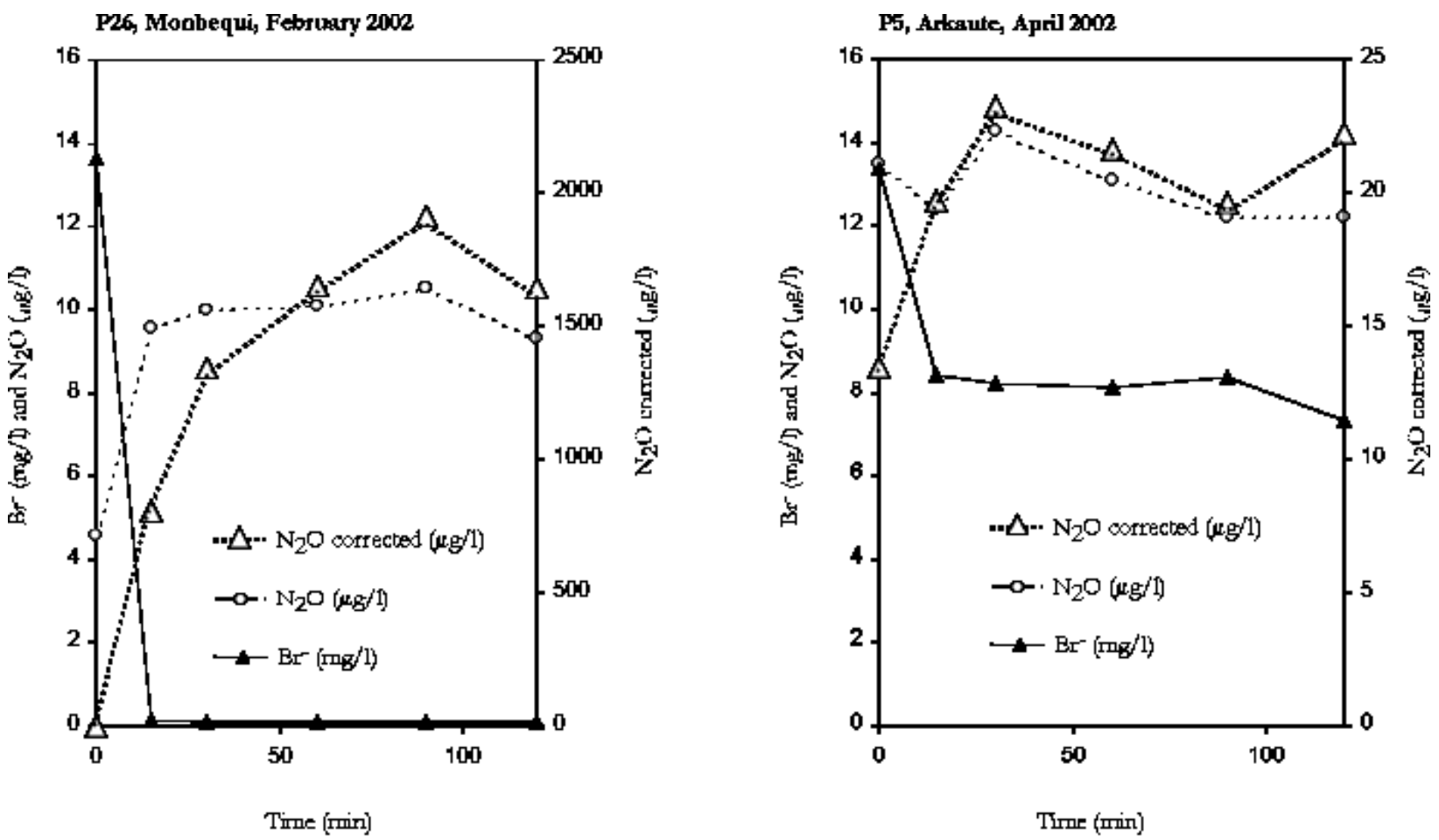

Fig. 4. Bromide, $\mathrm{N}_{2} \mathrm{O}$ and corrected $\mathrm{N}_{2} \mathrm{O}$ concentrations versus time with the dilution for two injection tests.

Table 4. Denitrification rate $\left(\mathrm{g} \mathrm{N}-\mathrm{NO}_{3}{ }^{-} \mathrm{L}^{-1} \mathrm{~h}^{-1}\right)$ measured by the tracer test $(\mathrm{P} 10$ and $\mathrm{P} 13$ were located in a riparian zone, $\mathrm{P} 8$ and $\mathrm{P} 10$ in a poplar plantation and $\mathrm{P} 26$ and $\mathrm{P} 29$ in an agricultural zone).

\begin{tabular}{lllllll}
\hline & $P 8$ & $P 9$ & $P 10$ & $P 13$ & $P 26$ & $P 29$ \\
\hline February & $3.7710^{-5}$ & $1.7710^{-5}$ & $6.5010^{-6}$ & $4.0610^{-5}$ & $2.1410^{-5}$ & $2.3410^{-5}$ \\
March & $1.2010^{-5}$ & $8.2410^{-6}$ & $1.0810^{-4}$ & $8.3010^{-5}$ & $1.2010^{-5}$ & $1.5110^{-5}$ \\
April & $2.1410^{-4}$ & $8.2410^{-6}$ & $1.0810^{-4}$ & $2.0610^{-3}$ & $5.2310^{-5}$ & $1.5710^{-5}$ \\
Mai & $6.5410^{-4}$ & $2.1010^{-5}$ & $9.7310^{-4}$ & $2.0410^{-3}$ & $1.0210^{-4}$ & $1.5310^{-5}$ \\
June & $3.0310^{-4}$ & $2.0210^{-4}$ & $1.1010^{-3}$ & $6.3310^{-4}$ & $2.4310^{-5}$ & $1.8710^{-5}$ \\
\hline
\end{tabular}




\section{HYDROGEOLOGICAL MODELLING}

The model grid comprises three horizontal layers (Fig. 5), the thickness of the second layer corresponding to the thickness of the interval isolated by the packer system. The size dimension of the grid is $10 \mathrm{~m} \times 10 \mathrm{~m}$ and the dimension of the cells is $20 \mathrm{~cm} \times 20 \mathrm{~cm}$. The depth of sampling section in the piezometer is around $3 \mathrm{~m}$ which corresponds to the mean underground depth at the study site during the experiments. Analysis of sensitivity to hydraulic conductivity was calculated over a hydraulic conductivity range of $10^{-1}$ to $10^{-8} \mathrm{~m} . \mathrm{s}^{-1}$. The hydraulic gradient of the water table is $0.3 \%$.

For the transport simulations, the ratios, horizontal transverse dispersivity/longitudinal dispersivity and vertical transverse dispersivity/longitudinal dispersivity are equal to 0.1 . The flow simultations by PM5 show that the pumping plan makes groundwater depth move by $0.16 \%$. The transport simulation results by MT3D (Fig 5, with $\mathrm{k}=10^{-4}$ $\mathrm{m} . \mathrm{s}^{-1}$ ) show that the pumping plan influenced only a 120 $\mathrm{cm}$ radius around the piezometer. Therefore, the sampled part of the aquifer was not disturbed significantly during the pumping operation. The top face (1) shows that the tracer injected was spread homogeneously all around the piezometer; the front (2) and side views (3) show that the tracer stays at the depth of the packer during the experiment and, therefore, the sampling was done in water blocked by $\mathrm{C}_{2} \mathrm{H}_{2}$.

The results of the model for different hydraulic conductivities in the physical context of the experiments are represented in Fig. 6. Concentrations of $\mathrm{Br}^{-}$were normalised according to the equation : $1-[(\mathrm{Cinj}-\mathrm{Ct}) /$ (Cinj - Cini)], with Cinj the concentration of $\mathrm{Br}^{-}$in the injection, Cini the initial concentration of $\mathrm{Br}^{-}$in the groundwater and $\mathrm{Ct}$ the concentration calculated by the model at each time step. Table 5 presents the initial and injected concentrations in the model. For a given hydraulic conductivity, normalisation gives the same results independently of the injected concentrations and of the initial conditions. The decrease of $\mathrm{Br}^{-}$due to dilution by dispersion is linked to the hydraulic conductivity of the aquifer. To sample the water blocked by $\mathrm{C}_{2} \mathrm{H}_{2}$ during the whole experiment and to calculate the denitrification rate, the method was optimal for values of $\mathrm{k}$ from $10^{-2}$ to $10^{-4} \mathrm{~m} \mathrm{~s}^{-1}$ in the physical and hydrological context.

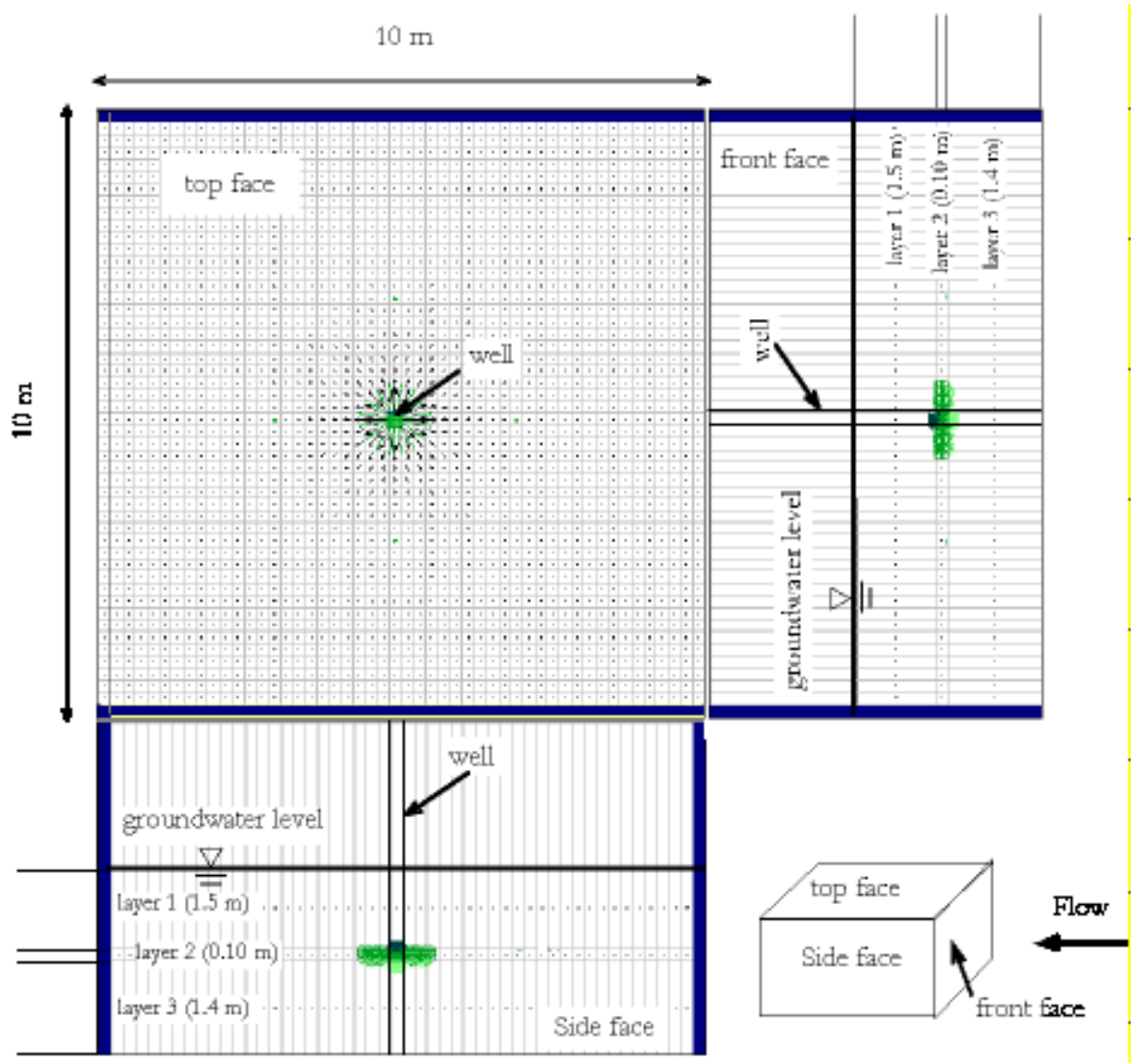

Fig. 5. Modelling injection in a piezometer with an aquifer hydraulic conductivity of $10^{-4} \mathrm{~m} \mathrm{~s}^{-1}$. 
Table 5. Concentrations used for modelling with different hydraulic conductivities.

\begin{tabular}{lccccccc}
\hline & \multicolumn{3}{c}{$\begin{array}{l}\text { Hydraulic conductivity from } \\
10^{-1} \text { to }\end{array} 0^{-8} \mathrm{~m} \mathrm{~s}^{-1}$} & \multicolumn{4}{c}{$\begin{array}{l}\text { Hydraulic conductivity } \\
10^{-3} \mathrm{~m} \mathrm{~s}^{-1}\end{array}$} \\
\hline $\begin{array}{l}\text { Initial concentration } \\
\left(\mathrm{mg} \mathrm{L}^{-1}\right)\end{array}$ & 0.1 & 0.1 & 0.1 & 0.1 & 0.5 & 1 & 5 \\
$\begin{array}{l}\text { Injected concentration } \\
\left(\mathrm{mg} \mathrm{L}^{-1}\right)\end{array}$ & 1 & 10 & 13.4 & 20 & 1 & 10 & 20 \\
\hline
\end{tabular}

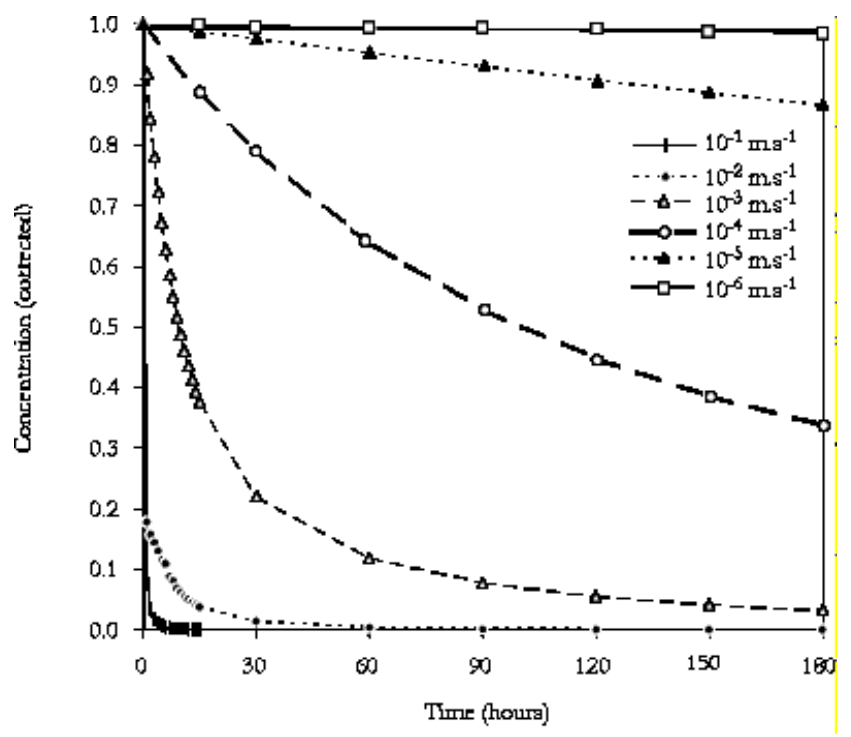

Fig. 6. Normalised concentration of bromide as a function of time for different hydraulic conductivities.

\section{Discussion}

The blockage of $\mathrm{N}_{2} \mathrm{O}$ reduction by acetylene is indeed valid for measurement of denitrification in soils and sediments, as well in the laboratory and in studies in situ. Studies have been done on soils and sediments, using core samples (Smith and Duff, 1988 ; Pinay et al., 1993; Bengtsson and Bergwall, 1995 ; Burt et al., 1999) or in situ microcosms (Starr and Gillham, 1993).

Some studies try to evaluate a denitrification rate in aquifers by bacteria located in the groundwater. $\mathrm{C}_{2} \mathrm{H}_{2}$ and a tracer, most often bromide, are injected in a piezometer and the evolution of bromide and $\mathrm{N}_{2} \mathrm{O}$ transported by groundwater is followed by means of surrounding piezometers; however, these experiments often require several days (Starr and Gillham, 1993; McMahon and Böhlke, 1996) and do not reveal how the mixture of bromide and acetylene is transported and what is really sampled. The flow from an assumed upstream piezometer to an assumed downstream one is too uncertain; moreover the $\mathrm{N}_{2} \mathrm{O}$ could be transformed into $\mathrm{N}_{2}$ as the $\mathrm{C}_{2} \mathrm{H}_{2}$ blockage may become inactive.

The results of the present model show that the concentration decrease in $\mathrm{Br}^{-}$depends directly on the hydraulic conductivity of the aquifer. During the experiment ( 2 hours) the dilution processes are dominated by dispersion. For this method, the hydrogeological conditions are optimal for a hydraulic conductivity between $10^{-2}$ and $10^{-4} \mathrm{~m} \mathrm{~s}^{-1}$. For a hydraulic conductivity higher than $10^{-2} \mathrm{~m} \mathrm{~s}^{-1}$, dilution mainly by dispersion is too high and the effect of the inhibition with the acetylene is reduced with time, which in turn makes the measurements very difficult. In contrast, for a hydraulic conductivity lower than $10^{-4} \mathrm{~m} \mathrm{~s}^{-1}$, the transfer into the aquifer is very weak, the tracer remains in the piezometer during the whole time of the experiment and $\mathrm{C}_{2} \mathrm{H}_{2}$ may decrease by dispersion or by exchange with air. As the concentration of $\mathrm{C}_{2} \mathrm{H}_{2}$ decreases during the experiment (sampling operation, dilution), total inhibition of $\mathrm{N}_{2} \mathrm{O}$ reductases cannot be considered efficient after 180 min in the experimental conditions.

Modifications of the environment caused by this method (oxygen entry to the aquifer, dilution process of the water volume studied) did not seem to modify microbial action significantly.

The use of $\mathrm{C}_{2} \mathrm{H}_{2}$ to measure the denitrification rates does not allow measurement of the denitrification of $\mathrm{NO}_{3}^{-}$ possibly produced by nitrification : acetylene not only inhibits the $\mathrm{N}_{2} \mathrm{O}$ reductases activity but also, even at lower concentrations, the ammonium mono-oxygenase (thus ammonium oxidizing bacteria and nitrification) (Hyman and Wood, 1985).

In the present study, because of the high nitrate concentrations, denitrification resulting from nitrification products was considered negligible compared to the denitrification of the circulating nitrates.

As neither nitrate, oxygen nor carbon concentrations change significantly during the injection experiment, it can be assumed that the linear part of the $\mathrm{N}_{2} \mathrm{O}$ increase within the water sampled gives information on the effective in situ denitrification rate. 
By this method, it is possible to measure the denitrification rates occurring within the alluvial aquifer and, therefore, the quantity of nitrogen that is exported to the atmosphere if the groundwater flux is known.

The denitrification rate measured here lies within the range of values reported in shallow groundwater of Ontario during a 10-day experiment by Trudell et al. (1986) : $7.810^{-6}$ to

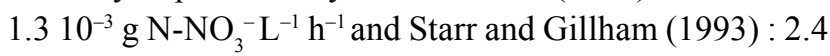

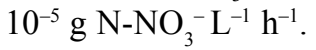

The acetylene method is not the only one to measure a denitrification rate; Addy et al. (2002) used the ${ }^{15} \mathrm{~N}$ method in a riparian aquifer at Rhode Island. However, the acetylene method is the most suitable for measuring denitrification in groundwater. The denitrification rates obtained by this method were in the range 17.6 to $22.410^{-6} \mathrm{~g} \mathrm{~N}^{-N^{-}} \mathrm{L}^{-1}$ $\mathrm{h}^{-1}$.

\section{DENITRIFICATION WITHIN A POROUS MEDIUM IS PLAYED BY BIOFILMS}

The results of this experiment also gave information on the sites where denitrification processes take place. Despite the presence of high concentrations of dissolved oxygen (from 0.6 up to $8.1 \mathrm{mg} \mathrm{O}_{2} \mathrm{~L}^{-1}$ ) during the experiments, denitrification detected in each sampled piezometer shows that microbial denitrification processes do not occur in interstitial water. Referring to previous studies on periphytic biofilms demonstrating that denitrification could occur within oxygenated water in superficial water (Nielsen et al., 1990; Teissier et al., 2002), it has been assumed that denitrification is localised within the biofilms growing around particles included in the sediments making up the porous aquifer.

\section{Conclusion}

A standardised method is proposed to measure in situ denitrification rates within the saturated zone of a porous aquifer. In addition, the hydrogeological model enables measurement of the hydraulic conductivity within the aquifer. This information, very important if the injection experiment can be undertaken in the given porous medium, also indicates the 'residence time' and dilution factor of interstitial water within the microenvironment of denitrification sites. This experiment shows that the denitrification process intensity is controlled, not only by the basic parameters, i.e. nitrate, carbon and dissolved oxygen, and by the permeability of the porous medium, but also by the biofilm metabolism and by the water exchanges between the biologically active sites (i.e. most probably biofilms) and the circulating interstitial water.
It is concluded that denitrification activity is negatively correlated with the hydraulic conductivity of the porous medium; the lower the permeability the higher the microbial community denitrification activity when carbon and nitrate are available. The conditions for this method are optimal for shallow aquifers with a hydraulic conductivity of $10^{-2}$ to $10^{-4} \mathrm{~ms}^{-1}$

\section{Acknowledgements}

These investigations were part of the ECOBAG program. The PNRZH (French National Programme of Research on Wetlands) and the Agence de l'Eau Adour-Garonne provided financial support for this project. The authors also wish to thank three anonymous referees for their valuable comments.

\section{References}

Addy, K.L., Kellogg, D.Q., Gold, A.J., Groffman, P.M., Ferendo, G. and Sawyer, C., 2002. In situ push-pull method to determinate groundwater denitrification in riparian zones. J. Environ. Qual., 31, 1017-1024.

Balderston, W.L., Sherr, B. and Payne, W.J., 1976. Blockage by acetylene of nitrous oxide reduction by Pseudomonas perfectomarinus. App. Environ. Microbiol., 31, 504-508.

Bengtsson G. and Bergwall C., 1995. Heterotrophic denitrification potential as an adaptative response in groundwater bacteria. Microbiol. Ecol., 16, 307-318.

Burt T.P., Matchett L.S., Goulding K.W.T., Webster C.P. and Haycock, N.E., 1999. Denitrification in riparian buffer zones : the role of floodplain hydrology. Hydrol.Process., 13, 14511463.

Cey, E.E., Rudolph, D.L., Parkin, G.W. and Aravena, R., 1999. Quantifying groundwater discharge to a small perennial stream in southern Ontario. Canada. J. Hydrol., 210, 21-37.

Chiang, W.H., Kinzelbach and Rausch, R. 1998. Aquifer Simulation Model for Windows-Groundwater flow and transport modeling, an integrated program. Gebrüder Borntraeger Berlin, Stuttgart, ISBN 3-443-01039-3

Cooper, A.B., 1990. Nitrate depletion in the riparian zone and stream channel of a small headwater catchment. Hydrobiologia, 202, 12-36.

Correll, D.L., Jordan, T.E. and Weller, D.E., 1992. Nutrient flux in a landscape: effects of coastal land use and terrestrial community mosaic on nutrient transport to coastal waters. Estuaries, 15, 431-442.

Gregory, S.V., Swanson, F.J., McKee, W. A. and Cummins, K.W., 1991. An ecosystem perspective of riparian zones. BioScience, 41, 540-551.

Haycock, N. E. and Pinay, G., 1993. Nitrate reduction in grass and poplar vegetated riparian buffer strips during the winter. $J$. Environ. Qual., 22, 273-278.

Hill, A. L. and Shackleton, M., 1989. Soil N mineralisation and nitrification to nitrogen solution chemistry in a small forested watershed. Water Res., 25, 1099-1111.

Hyman, M.R. and Wood, P.M., 1985. Suicidal inactivation and labelling of ammonia monooxygenase by acetylene. Biochem. $J .$, 227, 719-725. 
Jacobs, T.C. and Gilliam, J.W., 1985. Riparian losses of nitrates from agricultural drainage waters. J. Environ. Qual., 14, 472 478.

Jordan, T.E., Correll D.L. and Weller, D.E., 1993. Nutrient interception by a riparian forest receiving inputs from adjacent cropland. J. Environ. Qual., 22, 467-473.

Knowles, R., 1981. Denitrification. Ecol. Bull., 33, 315-329.

Knowles, R., 1982. Denitrification. Microbiol. Rev, 46, 43-70.

Knowles, R., 1990. Acetylene inhibition technique: development, advantages, and potential problems. In: Denitrification in soil and sediment, N.P. Revsbech and J. Sørensen, (Eds.), Plenum Press. 57-76.

Lowrance, R., Vellidis, G. and Hubbard, R.K., 1995. Denitrification in a restored riparian forest wetland. J. Environ. Qual., 24, 808-815.

Mc Donald, M.G. and Harbaugh, A.W., 1998. MODFLOW, A modular three-dimensional finite difference ground-water flow model. U.S. Geological Survey, Open-File report 83-875, Chapter A1.

McMahon, P.B. and Böhlke, J.K., 1996. Denitrification and mixing in a stream-aquifer system : effects on nitrate loading to surface water. J. Hydrol., 186, 105-128.

Nielsen, L.P., Christensen, P.B., Revsbech, N. P. and Sorensen, J., 1990. Denitrification and oxygen respiration in biofilms studied with a microsensor for nitrous oxide and oxygen. Microb. Ecol., 19, 63-72.

Payne, W.J., 1973. Reduction of nitrogenous oxide by microorganisms. Amer. Soc. Microbiol., 37, 409-452.

Peterjohn, W.T. and Correll, D.L., 1984. Nutrient dynamics in an agricultural watershed: observations on the rôle of a riparian forest. Ecology, 65, 1466-1475.

Pinay, G. and Décamps, H., 1988. The role of riparian woods in regulating nitrogen fluxes between the alluvial aquifer and surface water: A conceptual model. Regul. River., 2, 507-516.

Pinay, G., Roques, L. and Fabre, A., 1993. Spatial and temporal patterns of denitrification in a riparian forest. J.Appl. Ecol., 30, $581-591$

Pinay, G., Ruffinoni, C. and Fabre, A., 1995. Nitrogen cycling in two riparian forest soils under different geomorphic conditions. Biogeochemistry, 30, 9-29.
Sánchez-Pérez, J.M. and Trémolières, M. (2003). Change in groundwater chemistry as a consequence of suppression of floods : the case of the Rhine floodplain. J. Hydrol., 270, 89104.

Sánchez-Pérez, J. M., Trémolières, M. and Carbiener, R., 1991a. Une station naturelle d'épuration des phosphates et des nitrates apportés par les eaux de débordement du Rhin : la forêt alluviale à frêne et orme. C. R. Acad Sci. Paris, 112, 395-402.

Sánchez-Pérez, J.M., Trémolières, M., Schnitzler, A. and Carbiener, R., 1991b. Evolution de la qualité physico-chimique des eaux de la frange superficielle de la nappe phréatique en fonction du cycle saisonnier et des stades de succession des forêts alluviales rhénanes (Querco-Ulmetum). Acta Oecol., 12, 581-601.

Sánchez-Pérez, J.M. and Trémolières, M., 1997. Variations in nutrient levels of the groundwater in the upper Rhine alluvial forest as a consequence of hydrological regime and soil texture. Global Ecol. Biogeogr. Lett., 6, 211-217.

Seitzinger, S.P., Nielsen, L.P., Caffrey, J. and Christensen, P.B., 1993. Denitrification measurements in aquatic sediments: a comparison of three methods. Biogeochemistry, 23, 147-167.

Smith, R.L. and Duff, J.H., 1998. Denitrification in a Sand and Gravel Aquifer. App. Environ, Microbiol., 54, 1071-1078.

Starr, R.C. and Gillham, R.W., 1993. Denitrification and organic carbon availability in two aquifers. Ground Water, 31, 934 947.

Teissier, S., Garabétian, F., Torre, M., Dalger, D. and Labroue, L. (2002). Impact of an urban centre on the nitrogen cycle processes of epilithic biofilms during a summer low-water period. River Res. Appl., 18, 21-30.

Trudell, M.R., Gillham, R.H. and Cherry, J.A., 1986. An in-situ study of the occurrence and rate of denitrification in a shallow unconfined sand aquifer. J. Hydrol., 83, 251-286.

Weiss, R.F. and Price, B.A., 1980. Nitrous oxide solubility in water and seawater. Mar. Chem., 8, 347-359.

Yeomans, J.C. and Beauchamp, E.G., 1978. Limited inhibition of nitrous oxide reduction in soil in the presence of acetylene. Soil Biol. Chem., 10, 517-519.

Yoshinari, T. and Knowles, R., 1976. Acetylene inhibition of nitrous oxide reduction by denitrifying bacteria. Biochem. Biophys. Res. Comm., 69, 705-710. 